\title{
Analisis Pertambahan Pasien COVID-19 di Indonesia Menggunakan Metode Rantai Markov
}

\author{
Kinley Aritonang ${ }^{1}$, Alfian Tan ${ }^{2}$, Cherish Ricardo ${ }^{3}$, Dedy Surjadi ${ }^{4}$, Hanky Fransiscus ${ }^{5}$, Loren \\ Pratiwi $^{6}$, Marihot Nainggolan ${ }^{7}$, Sugih Sudharma ${ }^{8}$, Yani Herawati $^{9}$ \\ 1,23,4,5,5,6,7,9) Fakultas Teknologi Industri, Jurusan Teknik Industri, Universitas Katolik Parahyangan \\ Jl. Ciumbuleuit 94, Bandung 40141 Indonesia \\ Email: kinley@unpar.ac.id, alfian.tan@unpar.ac.id, cherish@unpar.ac.id, dedy@unpar.ac.id, \\ hanky.fransiscus@unpar.ac.id, lorenp@unpar.ac.id, marihot.nainggolan@unpar.ac.id, sugih.sudharma@unpar.ac.id, \\ yani.herawati@unpar.ac.id
}

\begin{abstract}
COVID-19 is a new disease that is affecting almost all of the world. Until now there has not been a single drug (vaccine) that can be used to cure it. Many attempts were made to prevent the spread of this disease but COVID-19 patients are increasing every day, although at the same time some are recovering. This study will calculate the probability of additional patients occurring over a long period of time, referred as a steady state state condition, using the Markov chain method. Nine states have been formed to represent the daily increase ranges of COVID-19 patients number. The calculation results show that the possibility of additional patient number between 1 to 91,92 to 182, 182 to 272, 273 to 363,364 to 454,455 to 545,546 to 636,637 to 727 , or greater than 728 people a day are 0.21197 , $0.05644,0.08408,0.16337,0.13999,0.14512,0.07189,0.07695$, and 0.05014 , respectively.
\end{abstract}

\section{Keywords: COVID-19, Daily Patient Increase, Markov Chain}

Penyakit COVID-19 adalah penyakit baru yang melanda hampir ke seluruh dunia. Sampai saat ini belum ada satu pun obat (vaksin) yang dapat digunakan untuk menyembuhkannya. Banyak usaha yang dilakukan untuk mencegah tersebarnya penyakit ini tetapi pasien COVID-19 setiap harinya selalu bertambah, walaupun pada saat yang sama ada juga yang sembuh. Penelitian ini akan menghitung kemungkinan terjadinya penambahan pasien pada jangka waktu yang lama, atau disebut dalam keadaan steady state, dengan menggunakan metode rantai Markov. Telah dibentuk 9 state yang merupakan rentang penambahan pasien COVID-19. Hasil perhitungan menunjukkan bahwa kemungkinan penambahan pasien antara rentang 1 sampai 91 orang adalah sebesar 0,21197 , antara 92 sampai 182 orang sebesar 0,05644 , antara 182 sampai 272 orang sebesar 0,08408 , antara 273 sampai 363 sebesar 0,16337 , antara 364 sampai 454 sebesar 0,13999 , antara 455 sampai 545 sebesar 0,14512 , antara 546 sampai 636 orang sebesar 0,07189 , antara 637 sampai 727 orang sebesar 0,07695 , dan lebih besar dari 728 orang sebesar 0,05014 .

Kata kunci: COVID-19, Penambahan Pasien per Hari, Rantai Markov

\section{Pendahuluan}

Virus corona (coronavirus) merupakan sebuah virus yang menyebabkan infeksi saluran pernapasan atas seperti flu. Beberapa jenis virus corona dapat menyebabkan penyakit yang lebih serius seperti pneumonia, Middle East Respiratory Syndrome (MERSCoV), dan Severe Acute Respiratory Syndrome (SARS-CoV). Jenis virus corona yang baru ditemukan pada akhir tahun 2019. Virus ini pertama kali ditemukan di Wuhan, Provinsi Hubei, Tiongkok. Awalnya virus ini diberi nama 2019 novel Coronavirus (2019-
nCoV). Tanggal 11 Februari 2020, World Health Organization (WHO) memberi nama virus corona yang baru tersebut Severe Acute Respiratory Syndrome Coronavirus-2 (SARSCoV-2) dan nama penyakitnya adalah Coronavirus disease 2019 (COVID-19) (Yuliana, 2020).

Gejala dari Infeksi COVID-19 dapat merupakan gangguan ringan, sedang, atau berat. Gejala klinis utama dari COVID-19 adalah demam (suhu $>38^{\circ} \mathrm{C}$ ), batuk, dan kesulitan bernapas (Yuliana, 2020). Bagi lansia dan orang dengan penyakit penyerta (memiliki riwayat sakit diabetes, jantung, dan hipertensi), 
penyakit ini dapat menyebabkan kematian. Bagi kelompok yang berusia muda dan memiliki daya tahan tubuh yang baik, penyakit ini dapat sembuh dengan isolasi mandiri. COVID-19 menyebar dengan cepat hampir ke seluruh negara di dunia, termasuk Indonesia. Keadaan yang disebabkan oleh penyakit ini sudah dideklarasikan sebagai Darurat Kesehatan Masyarakat secara Global (Global Public Health Emergency) oleh WHO. Penyakit ini masih baru dan penelitian mengenai penyakit ini masih sangat sedikit.

Penyakit ini telah menimbulkan satu bentuk etika di masyarakat untuk menjalani kehidupan yang tidak merugikan pihak lain (Fong \& Devanand, 2020). Kerugian besar telah ditimbulkan oleh pandemi ini termasuk kematian pada manusia. Pandemi ini membuat ketidakstabilan di bidang sosial dan ekonomi. Semua pihak harus terlibat dalam melindungi masyarakat agar aman dalam pandemi ini. Pemerintah, sektor swasta, akademisi, dan profesional, serta setiap warga negara lainnya perlu dilibatkan dengan peranannya masing-masing dalam membangun masyarakat yang tangguh dalam hal kesehatan, ekonomi, dan ketahanan sosial. Pemberdayaan warga negara sangat penting dalam mengurangi dampak pandemi, termasuk kemampuan untuk beradaptasi dengan guncangan, kepanikan, dan tekanan dan untuk dengan cepat menanggapi lingkungan yang tidak stabil (Berawi et al., 2020).

Sampai saat ini obat untuk penyakit ini belum diketemukan, dan upaya untuk menemukan obat terus dilakukan oleh banyak peneliti di seluruh dunia. Pemerintah Indonesia saat ini sudah merancang program Normal Baru (New Normal), juga merupakan program WHO, yang mana masyarakat akan melangsungkan kegiatan kehidupannya dengan aturan-aturan tertentu yang baru agar dapat hidup berdampingan dengan penyakit ini.

Penelitian ini melakukan analisa pertambahan pasien COVID-19 per hari, dengan tujuan untuk mengetahui jumlah pasien dalam jangka panjang yang disebut dalam keadaan Steady State. Penelitian ini menggunakan asumsi sebagai berikut:

1. Belum ada obat atau vaksin diketemukan untuk penyakit COVID-19.

2. Pola kehidupan masyarakat Indonesia dimodelkan mengikuti kebijakan protokol kesehatan pada periode 19 Maret sampai 31 Mei 2020, sehingga data yang digunakan adalah data pada periode tersebut..

Tabel 1 menunjukkan penambahan pasien penyakit COVID-19 di Indonesia. Banyak usaha yang sudah dilakukan oleh pemerintah dan masyarakat selama Maret sampai Mei 2020 untuk mengurangi tingkat penyebaran COVID-19 sebagai upaya mengurangi jumlah pasien terinfeksi. Estimasi efektivitas terhadap segala upaya dalam 2,5 bulan tersebut perlu dilakukan, salah satunya dengan melihat distribusi pertambahan jumlah pasien terinfeksi per harinya serta total pasien COVID 19 di Indonesia dalam jangka panjang. Informasi ini akan memberi masukan bagi pihak berwenang terkait efektif tidaknya keputusan-keputusan yang sudah diambil dalam memenuhi tujuan akhir kondisi penyebaran COVID-19 di Indonesia. Lebih jauh lagi, pihak-pihak pengambil keputusan dapat melakukan perubahan yang diperlukan apabila memang usaha-usaha yang selama ini dilakukan belum sesuai harapan.

Tabel 1. Penambahan pasien COVID-19 di Indonesia (19 Maret 2020 sampai tanggal 31 Mei 2020)

\begin{tabular}{|c|c|c|c|c|c|}
\hline $\begin{array}{l}\text { Tang } \\
\text { gal }\end{array}$ & $\begin{array}{l}\text { Penam } \\
\text { bahan }\end{array}$ & $\begin{array}{l}\text { Tang } \\
\text { gal }\end{array}$ & $\begin{array}{l}\text { Penam } \\
\text { bahan }\end{array}$ & $\begin{array}{l}\text { Tang } \\
\text { gal }\end{array}$ & $\begin{array}{l}\text { Penam } \\
\text { bahan }\end{array}$ \\
\hline $19-3$ & 82 & $13-4$ & 316 & 08-5 & 336 \\
\hline 20-3 & 60 & 14-4 & 282 & $09-5$ & 533 \\
\hline $21-3$ & 81 & $15-4$ & 297 & $10-5$ & 387 \\
\hline $22-3$ & 64 & $16-4$ & 380 & $11-5$ & 233 \\
\hline $23-3$ & 65 & $17-4$ & 407 & $12-5$ & 484 \\
\hline $24-3$ & 107 & $18-4$ & 325 & 13-5 & 689 \\
\hline $25-3$ & 104 & $19-4$ & 327 & $14-5$ & 568 \\
\hline $26-3$ & 103 & $20-4$ & 185 & $15-5$ & 490 \\
\hline $27-3$ & 153 & $21-4$ & 375 & 16-5 & 529 \\
\hline 28-3 & 109 & $22-4$ & 283 & $17-5$ & 489 \\
\hline $29-3$ & 130 & $23-4$ & 357 & $18-5$ & 496 \\
\hline $30-3$ & 129 & $24-4$ & 436 & 19-5 & 486 \\
\hline $31-3$ & 114 & $25-4$ & 396 & $20-5$ & 693 \\
\hline $01-4$ & 149 & $26-4$ & 275 & $21-5$ & 973 \\
\hline $02-4$ & 113 & $27-4$ & 214 & $22-5$ & 634 \\
\hline 03-4 & 196 & $28-4$ & 415 & $23-5$ & 949 \\
\hline 04-4 & 106 & $29-9$ & 260 & $24-5$ & 526 \\
\hline 05-4 & 181 & $30-4$ & 347 & $25-5$ & 479 \\
\hline $06-4$ & 218 & $01-5$ & 433 & 26-5 & 415 \\
\hline $07-4$ & 247 & $02-5$ & 292 & $27-5$ & 786 \\
\hline $08-4$ & 218 & 03-5 & 349 & $28-5$ & 587 \\
\hline 09-4 & 337 & $04-5$ & 397 & $29-5$ & 678 \\
\hline $10-4$ & 219 & $05-5$ & 482 & $30-5$ & 557 \\
\hline $11-4$ & 330 & $06-5$ & 367 & $31-5$ & 700 \\
\hline $12-4$ & 399 & $07-5$ & 338 & & \\
\hline
\end{tabular}

Sumber: kawalcovid19.id (2020)

Metode yang akan digunakan untuk pemodelan jumlah pertambahan pasien per hari dalam penelitian ini adalah rantai Markov (Markov Chain). Rantai Markov merupakan sebuah metode yang dapat digunakan untuk memodelkan secara stokastik perubahan nilai variabel acak atau keadaan dari waktu-waktu (Winston \& Goldberg, 2004). Penerapan rantai Markov ini sangat luas dan salah satunya adalah dalam pemodelan penyebaran virus. Beberapa penelitian terkait penyebaran virus yang pernah dilakukan dan melibatkan rantai Markov dalam pemodelannya antara lain kasus penyebaran virus citrus tristeza pada tanaman (Gibson, 1997), kasus pandemi virus H1N1 (Lemey et al., 2009), dan kasus ebola (Merler et al., 2015). Dalam ketiga penelitian tersebut, rantai Markov dimodelkan dengan titik-titik waktu yang kontinu 
atau dimanfaatkan juga sebagai alat kalibrasi model penyebaran virus yang lebih besar. Pada penelitian kali ini, metode rantai Markov akan digunakan juga untuk memodelkan kejadian pertambahan pasien terinfeksi COVID-19 dari hari ke hari dengan dasar kondisi kebijakan di Maret hingga Mei 2020. Bentuk dasar rantai Markov sebagai metode pemodelan discrete time stochastic process akan digunakan dengan rentang jumlah pertambahan pasien per hari sebagai keadaan/variabel acak atau dalam teori rantai Markov disebut state.

\section{Metodologi}

Rantai Markov dapat digambarkan sebagai discrete-time stochastic process yang memiliki jumlah state yang terbatas (diberi label 1.....s) dan pada suatu saat rantai Markov berada di salah satu state tersebut (Winston \& Goldberg, 2004). Keadaan ini dapat dituliskan pada Pers. 1.

$\begin{aligned} P\left(X_{t+1}=\right. & i_{t+1} \mid X_{t}=i_{t}, X_{t-1}= \\ & \left.i_{t-1}, \ldots \ldots \ldots, X_{1}=i_{1}, X_{0}=i_{0}\right)\end{aligned}$

Pers. 1

Dimana:

$X_{t}$ : variabel discrete time stochastic process pada waktu $\mathrm{t}$.

it : State dari discrete time stochastic process pada waktu t.

Pers. 1 menjelaskan bahwa distribusi probabilitas state pada saat $t+1$ tergantung pada state pada waktu $t$ (state sebelumnya) dan tidak tergantung dari rantai Markov untuk mencapai state pada waktu t tersebut. Hal ini dapat dituliskan seperti pada Pers. 2.

$P\left(X_{t+1}=i_{t+1} \mid X_{t}=i_{t}\right)=p_{i j}$

Pers. 2

$p_{i j}$ adalah kemungkinan bahwa sistem ada pada state $i$ pada waktu $t$ dan akan berada di state $j$ pada waktu $t+1$. Jika pada suatu periode sistem berubah dari state $i$ ke state $j$, maka dapat dikatakan ada sebuah transisi dari state $i$ ke state $j$. $p_{i j}$ 's dapat dikatakan sebagai kemungkinan transisi dari rantai Markov untuk satu periode atau satu langkah. Seluruh state $i$ dan $j$ dan seluruh waktu $t$ diasumsikan independen. Kemungkinan matriks transisi $P$ dapat dituliskan seperti pada Pers. 3.

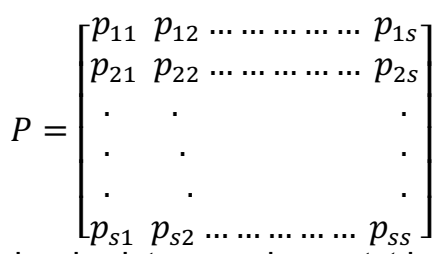

Pers 3

Jika sebuah sistem pada saat $t$ berada pada state $i$, maka sistem ini pada saat $t+1$ ada pada state lain. Hal ini berarti bahwa: $\sum_{j=1}^{j=s} P\left(X_{t+1}=j \mid P\left(X_{t}=i\right)\right)=\sum_{j=1}^{j=s} p_{i j}=1$

Pers. 4

Sebuah rantai Markov dapat dianalisis jika rantai Markov tersebut memiliki state-state yang bersifat ergodic (recurrent, aperiodic, dan communicate). Pada penelitian ini didefinisikan bahwa:

1. Variabel $X_{t}$ adalah sistem penambahan pasien COVID-19 yang diamati pada waktu $t$ (tanggal pengamatan penambahan pasien).

2. Variabel $i$ adalah state atau nilai penambahan pasien COVID-19 pada waktu t. Sebagai contoh: state pada tanggal 4 April adalah 106 yang artinya pada tanggal tersebut ada penambahan pasien 106.

Pada penelitian ini akan diturunkan kemungkinan dari sebuah state dalam jangka panjang. Keadaan ini disebut keadaan steady state di mana rantai Markov akan settles down dan secara independen terhadap state awal $i$ dengan kemungkinan $m_{j}$ rantai Markov akan berada pada state $j$. Keadaan ini dapat dituliskan seperti pada Pers. 5.

$$
\lim _{t \rightarrow \infty} P_{i j}(t)=m_{j}
$$

Pers. 5

Vektor $m=\left[\begin{array}{llll}m_{1} & m_{2} & \ldots \ldots . & m_{s}\end{array}\right]$ disebut distribusi steady state untuk rantai Markov. Sifat untuk nilai $t$ yang besar dan untuk semua $i$ dapat dituliskan seperti dalam Pers. 6 berikut.

$$
\begin{aligned}
P_{i j}(t+1) & \approx P_{i j}(t) \approx m_{j} \\
m_{j} & =\sum_{k=1}^{k=s} P_{i k}(t) p_{k j}
\end{aligned}
$$$$
\text { Pers.6 }
$$

Untuk $t$ yang besar, persamaan 7 berikut dapat digunakan:

$$
m_{j}=\sum_{k=1}^{k=s} m_{k} p_{k j}
$$

Pers. 7

Di dalam bentuk matriks dapat dituliskan seperti di Pers. 8.

$$
m=m P
$$

Pers.8

Sistem Pers. 8 memiliki jumlah solusi yang infinite yang disebabkan rank matriks $P$ selalu $\leq s-1$. Oleh sebab itu untuk mendapatkan nilai unik untuk kemungkinan pada keadaan steady state dan sekaligus juga berdasarkan Pers. 4, Pers. 8 akan ditambahkan Pers. 9 berikut. 


$$
m_{1}+m_{2}+\ldots \ldots \ldots+m_{s}=1 \quad \text { Pers. } 9
$$

Persoalan timbul dalam pemodelan terkait penggolongan state yang terjadi. Penggolongan dilakukan berdasarkan pertimbangan terpenuhi atau tidak terpenuhi syarat dari Markov Chain yang Ergodic. Trial and error telah dilakukan untuk membentuk state, sehingga pada akhirnya ditemukanlah state ini. Terlalu banyak state yang pada waktu selanjutnya tidak akan pernah dikunjungi kembali. Sebagai contoh state 106, yang terjadi pada tanggal 4 April, untuk selanjutnya tidak akan pernah terjadi lagi. Pada rantai Markov, keadaan ini disebut absorbing chain. Analisa absorbing chain mempersyaratkan bahwa sebuah state tidak akan pernah dikunjungi kembali pada saat yang akan datang. Sementara itu state 218 terjadi pada tanggal 6 April dan state ini kembali akan dikunjungi pada tanggal 8 April, maka state tersebut bukan absorbing chain.

Dengan demikian dapat disimpulkan bahwa data yang diperoleh pada Tabel 1 tidak dapat dianalisa menggunakan model absorbing chain. Untuk mengatasi hal ini, dilakukan pendekatan di mana akan dibentuk beberapa state yang merepresentasikan range penambahan nilai pasien COVID-19. Tabel 2 menampilkan range yang digunakan.

Selanjutnya data pada Tabel 1 akan diterjemahkan berdasarkan golongan state di Tabel 2 dan dilakukan pencatatan frekuensi transisi dari hari ke hari terkait penambahan pasien COVID-19. Sebagai contoh;

1. Terjadi transisi dari state 1 ke state 1 sebanyak 4 kali (19 Maret, 20 Maret, 21 Maret, dan 22 Maret).
2. Terjadi transisi dari state 3 ke state 2 sebanyak satu kali (3 April).

Tabel 2. Range Penambahan Pasien COVID19

\begin{tabular}{|c|c|}
\hline $\begin{array}{c}\text { Range Penambahan } \\
\text { Pasien COVID19 }\end{array}$ & State ke \\
\hline $1-90$ & 1 \\
\hline $91-181$ & 2 \\
\hline $182-272$ & 3 \\
\hline $273-363$ & 4 \\
\hline $364-454$ & 5 \\
\hline $455-545$ & 6 \\
\hline $546-636$ & 7 \\
\hline $637-727$ & 8 \\
\hline$\geq 728$ & 9 \\
\hline
\end{tabular}

3. Terjadi transisi dari state 5 ke state 3 sebanyak dua kali (28 April dan $10 \mathrm{Mei}$ ).

Berdasarkan data 19 Maret sampai tanggal 31 Mei 2020, didapatkan frekuensi transisi pada Tabel 3. Berdasarkan Tabel 3 dan Pers. 4 dapat dibentuk matriks pada Pers. 10 yang berisi nilai probabilitas transisi $P$ untuk data penambahan pasien COVID19 di Indonesia sejak tanggal 19 Maret 2020 sampai tanggal 31 Mei 2020 (sesuai dengan data yang tersedia).

Transisi matriks pada Pers. 10 digambarkan pada Gambar 1 di mana setiap node, state dan panah $(i, j)$ (arc ij) merepresentasikan kemungkinan transisi $p_{i j}$. Gambar 1 menunjukkan bahwa rantai Markov ini adalah aperiodic, communicate, dan recurrent. Dengan demikian dapat dikatakan bahwa rantai Markov adalah ergodic sehingga rantai Markov ini dapat dianalisis lebih lanjut.

Berdasarkan Pers. 8 dan Pers. 10, dapat dibentuk Pers. 11-19 untuk memperoleh nilai kemungkinan terjadinya state tertentu pada keadaan steady state.

Tabel 3. Frekuensi Transisi

\begin{tabular}{|l|c|c|c|c|c|c|c|c|c|}
\hline & state 1 & state 2 & state 3 & state 4 & state 5 & state 6 & state 7 & state 8 & state 9 \\
\hline state 1 & 4 & 1 & 0 & 0 & 0 & 0 & 0 & 0 & 0 \\
\hline state 2 & 9 & 1 & 2 & 0 & 0 & 0 & 0 & 0 & 0 \\
\hline state 3 & 0 & 1 & 2 & 3 & 2 & 1 & 0 & 0 & 0 \\
\hline state 4 & 0 & 0 & 3 & 6 & 5 & 1 & 0 & 0 & 0 \\
\hline state 5 & 0 & 0 & 2 & 6 & 2 & 1 & 0 & 0 & 1 \\
\hline state 6 & 0 & 0 & 0 & 0 & 3 & 5 & 0 & 2 & 0 \\
\hline state 7 & 0 & 0 & 0 & 0 & 0 & 1 & 0 & 2 & 0 \\
\hline state 8 & 0 & 0 & 0 & 0 & 0 & 0 & 1 & 0 & 1 \\
\hline state 9 & 0 & 0 & 0 & 0 & 0 & 1 & 2 & 0 & 0 \\
\hline
\end{tabular}


DOI: https://doi.org/10.26593/irsi.v9i2.3998.69-76

$P=\left[\begin{array}{ccccccccc}0,8000 & 0,2000 & 0 & 0 & 0 & 0 & 0 & 0 & 0 \\ 0,7500 & 0,0833 & 0,1667 & 0 & 0 & 0 & 0 & 0 & 0 \\ 0 & 0,1111 & 0,2222 & 0,3333 & 0,2222 & 0,1111 & 0 & 0 & 0 \\ 0 & 0 & 0,2000 & 0,4000 & 0,3333 & 0,0667 & 0 & 0 & 0 \\ 0 & 0 & 0,1667 & 0,5000 & 0,1667 & 0,0833 & 0 & 0 & 0,0833 \\ 0 & 0 & 0 & 0 & 0,3000 & 0,5000 & 0 & 0,2000 & 0 \\ 0 & 0 & 0 & 0 & 0 & 0,3333 & 0 & 0,6667 & 0 \\ 0 & 0 & 0 & 0 & 0 & 0 & 0,5000 & 0 & 0,5000 \\ 0 & 0 & 0 & 0 & 0 & 0,3333 & 0,6667 & 0 & 0\end{array}\right]$ Pers. 10

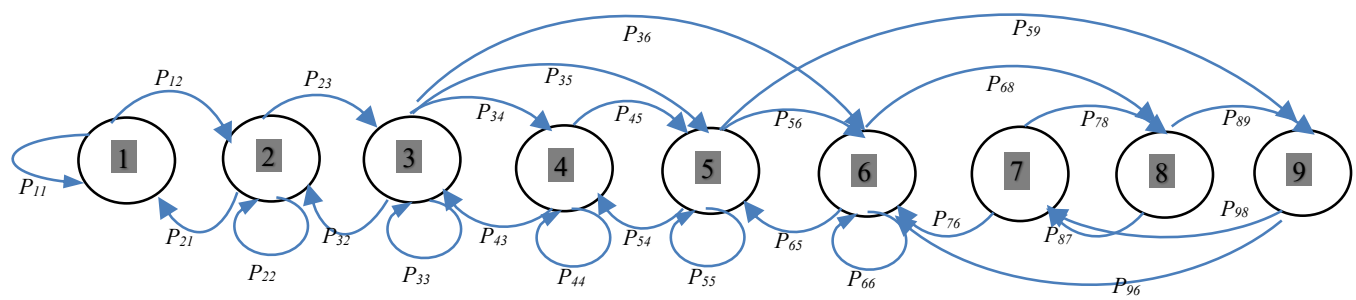

Gambar 1. Transisi Probabilitas antara State

$$
\begin{aligned}
m_{1}= & 0,8 m_{1}+0,75 m_{2} \\
m_{2}= & 0,2 m_{1}+0,0833 m_{2}+ \\
& 0,1111 m_{3} \\
m_{3}= & 0,1667 m_{2}+0,2222 m_{3}+ \\
& 0,2 m_{4}+0,1667 m_{5} \\
m_{4}= & 0,3333 m_{3}+0,4 m_{4}+0,5 m_{5} \\
m_{5}= & 0,2222 m_{3}+0,3333 m_{4}+ \\
& 0,1667 m_{5}+0,3 m_{6} \\
m_{6}= & 0,1111 m_{3}+0,0667 m_{4}+ \\
& 0,0833 m_{5}+0,5 m_{6}+ \\
& 0,3333 m_{7}+0,3333 m_{9} \\
m_{7}= & 0,5 m_{8}+0,6667 m_{9} \\
m_{8}= & 0,2 m_{6}+0,6667 m_{7} \\
m_{9}= & 0,0833 m_{5}+0,5 m_{8}
\end{aligned}
$$

\section{Hasil dan Diskusi}

Persamaan 11-19 di atas bersama dengan Pers. 9, akan menghasilkan solusi berikut:

$m_{1}=0,21197$

$m_{2}=0,05644$

$m_{3}=0,08408$

$m_{4}=0,16337$

$m_{5}=0,13999$

$m_{6}=0,14512$

$m_{7}=0,07189$

$m_{8}=0,07695$

$m_{9}=0,05014$

Pembuatan range jumlah penambahan pasien COVID-19 per hari yang merepresentasikan state dari rantai Markov ini perlu diperhatikan. Range yang terlampau kecil dapat mengakibatkan adanya absorbing chain atau ada state yang tidak akan pernah dikunjungi. Jika kedua hal ini terjadi maka pembuatan range harus diulangi kembali.
Pers. 11

Pers. 12

Pers. 13

Pers. 14

Pers. 16

Pers. 17

Pers. 18

Pers. 19

Range yang terlampau besar dapat juga mengakibatkan terjadinya absorbing chain atau frekuensi transisi pada suatu state menjadi sangat besar.

Hasil ini bisa berubah jika terjadi keadaan berikut:

1. Tersedianya tambahan data baru. Dengan adanya lebih banyak data, maka hasil pun akan lebih baik atau lebih merepresentasikan sistem dan perhitungan.

2. Pola kehidupan masyarakat Indonesia berubah. Pada saat studi ini dilakukan, pemerintah Indonesia sedang mencanangkan pola kehidupan new normal. Jika masyarakat Indonesia patuh mengikuti pola ini, maka perubahan data pada penambahan pasien COVID-19 dapat terjadi.

3. Diketemukannya obat vaksin penyakit COVID-19. Jika obat ini sudah diketemukan, maka pola penambahan pasien juga akan berubah.

Berdasarkan hasil pemodelan yang dilakukan, peluang kondisi penambahan jumlah pasien COVID-19 per hari yang potensial atau memiliki peluang cukup berarti adalah pada state 1 (1-90), state 4 (273-363), state 5 (364-454), state 6 (455-545). Apabila rataannya dihitung, maka jumlah penambahan pasien COVID-19 mencapai angka 349,64 orang. Angka penambahan jumlah pasien ini cukup tinggi walaupun kondisi yang dimodelkan ini adalah kondisi saat pemerintah 
menerapkan kebijakan Pembatasan Sosial Berskala Besar (PSBB) dan protokol kesehatan yang ketat.

Pada kondisi pembatasan yang cukup ketat di Maret hingga Mei 2020 ini, jumlah rata-rata penambahan pasien per hari bisa mewakili dua hal yaitu kinerja tim penanggulangan COVID19 dalam mendeteksi pasien terinfeksi yang sudah ada di tengah masyarakat dan sekaligus di dalamnya jumlah pasien baru yang terinfeksi dengan kondisi interaksi masyarakat di masa tersebut. Secara logis, keadaan di masa pembatasan yang ketat ini akan menekan penularan yang terjadi sehingga sebenarnya angka rerata penambahan jumlah pasien per hari ini bisa dikatakan lebih menunjukkan jangkauan deteksi tim gugus tugas penanggulangan COVID-19 terhadap pasien terinfeksi. Masa-masa pembatasan yang ketat ini menjadi periode yang tepat untuk tim gugus tugas melakukan usaha yang sebesarbesarnya dan seluas-luasnya untuk mendeteksi pasien terinfeksi COVID-19.

Populasi pasien terinfeksi COVID-19 di tengah masyarakat ini sebenarnya belum diketahui jumlahnya sehingga usaha pendeteksian pasien terinfeksi pun perlu terus dilakukan. Rata-rata jumlah penambahan pasien per hari dengan usaha dan cakupan pendeteksian yang diterapkan pun harus dipantau secara berkala hingga angka rerata jumlah penambahan pasien per harinya mencapai titik balik dan akhirnya memiliki tren menurun. Pada saat itulah sebenarnya waktu yang tepat bagi pemerintah untuk mempertimbangkan pelonggaran pembatasan secara proporsional. Tanpa melihat hal ini maka dari sudut pandang penyebaran kasus COVID-19, kebijakan pelonggaran yang diambil justru akan memperburuk risiko penyebaran COVID-19 dan memperberat tugas dari tim penanganan COVID-19. Namun demikian, sudut pandang yang digunakan dalam mengambil keputusan pelonggaran secara proporsional ini memang perlu melibatkan faktor sosial lainnya. Faktor ekonomi dan kesejahteraan hidup masyarakat menjadi faktor penting yang dipertimbangkan pemerintah saat ini sehingga protokol New Normal akhirnya diberlakukan.

Pertambahan jumlah pasien COVID-19 per hari yang melonjak jauh pada masa New Normal ini sebenarnya menunjukkan bahwa kasus pandemik COVID-19 di Indonesia belum mencapai puncaknya yang mungkin akan diperlambat dengan kondisi new normal saat ini. Dalam kondisi saat ini protokol new normal sebenarnya tidak bisa diberlakukan secara luas sekaligus, pembatasan dan pendeteksian yang cukup ketat penting untuk tetap dilakukan, namun secara spesifik pada daerah-daerah atau sub daerah yang masih dinilai sebagai zona merah dan hitam.

\section{Kesimpulan}

Dengan memperhatikan asumsi penelitian maka dapat disimpulkan bahwa pada keadaan steady state (pada jangka waktu yang panjang) probabilitas penambahan pasien COVID-19 akan mengikuti distribusi seperti pada Tabel 4.

Tabel 4. Kemungkinan Kenaikan Pasien COVID-19 pada Keadaan Steady State

\begin{tabular}{|c|c|}
\hline $\begin{array}{c}\text { Range Penambahan Pasien } \\
\text { COVID19 }\end{array}$ & Probabilitas \\
\hline $1-90$ & 0,21197 \\
\hline $91-181$ & 0,05644 \\
\hline $182-272$ & 0,08408 \\
\hline $273-363$ & 0,16337 \\
\hline $364-454$ & 0,13999 \\
\hline $455-545$ & 0,14512 \\
\hline $546-636$ & 0,07189 \\
\hline $637-727$ & 0,07695 \\
\hline$\geq 728$ & 0,05014 \\
\hline
\end{tabular}

Dari Tabel 4 dapat disimpulkan bahwa pada keadaan steady state kemungkinan penambahan pasien COVID-19 antara 1 sampai 91 adalah 0,21197 , rentang antara 92 sampai 182 adalah 0,05644 , rentang 182 sampai 272 adalah 0,08408 , rentang 273 sampai 363 adalah 0,16337 , rentang 364 sampai 454 adalah 0,13999 , rentang 455 sampai 545 adalah 0,14512 , rentang 546 sampai 636 adalah 0,07189 , rentang 637 sampai 727 adalah 0,07695 , dan rentang lebih besar 728 adalah 0,05014 .

\section{Daftar Pustaka}

Berawi, M. A., Suwartha, N., Kusrini, E., Yuwono, A. H., Harwahyu, R., Setiawan, E. A., Yatmo, Y. A., Atmodiwirjo, P., Zagloel, Y. T., \& Suryanegara, M. (2020). Tackling the COVID-19 Pandemic: Managing the Cause, Spread, and Impact. International Journal of Technology, 11(2), 209-214.

Fong, J. M. N., \& Devanand, A. (2020). Health Ethics in COVID-19: No Better Time for Solidarity. Singapore Medical Journal.

Gibson, G. J. (1997). Markov Chain Monte Carlo Methods for Fitting Spatiotemporal Stochastic Models in Plant Epidemiology. Journal of the Royal Statistical Society: Series C (Applied Statistics), 46(2), 215233.

kawalcovid19.id. (2020). COVID-19 di Indonesia. Kawalcovid19.Id.

Lemey, P., Suchard, M., \& Rambaut, A. (2009). Reconstructing the Initial Global Spread of a Human Influenza Pandemic: 
A Bayesian Spatial-temporal Model for the Global Spread of H1N1pdm. PLoS Currents, 1.

Merler, S., Ajelli, M., Fumanelli, L., Gomes, M. F. C., Piontti, A. P. y, Rossi, L., Chao, D. L., Longini, I. M., Halloran, M. E., \& Vespignani, A. (2015). Spatiotemporal Spread of the 2014 Outbreak of Ebola Virus Disease in Liberia and the Effectiveness of Non-pharmaceutical Interventions: A Computational Modelling
Analysis. The Lancet Infectious Diseases, 15(2), 204-211. https://doi.org/https://doi.org/10.1016/S14 73-3099(14)71074-6.

Winston, W. L., \& Goldberg, J. B. (2004). Operations Research: Applications and Algorithms (3rd ed.). Thomson Brooks/Cole Belmont.

Yuliana (2020). Corona Virus Disease (Covid19): Sebuah Tinjauan Lieratur. Wellness and Healthy Magazine, 2(1), 187-192. 
DOI: https://doi.org/10.26593/irsi.v9i2.3998.69-76

Halaman ini sengaja dikosongkan.

This page is intentionally left blank. 